OPEN ACCESS

Edited by:

Yujie Chen,

Army Medical University, China

Reviewed by:

Shengli Hu,

Army Medical University, China María Gutiérrez Fernández, University Hospital La Paz, Spain

*Correspondence: Xin Li

xlidoct@qq.com

Yuelin Zhang

orzhangyuelin1999@163.com

${ }^{t}$ These authors have contributed equally to this work

Specialty section:

This article was submitted to Cellular Neurophysiology, a section of the journal

Frontiers in Cellular Neuroscience

Received: 13 November 2020

Accepted: 14 January 2021

Published: 09 February 2021

Citation:

Li W, Shi L, Hu B, Hong Y,

Zhang H, Li X and Zhang Y (2021)

Mesenchymal Stem Cell-Based

Therapy for Stroke: Current

Understanding and Challenges.

Front. Cell. Neurosci. 15:628940.

doi: 10.3389/fncel.2021.628940

\section{Mesenchymal Stem Cell-Based Therapy for Stroke: Current Understanding and Challenges}

\author{
Weifeng $\mathrm{Li}^{1 \dagger}$, Linli Shi ${ }^{1,2+}$, Bei Hu${ }^{1}$, Yimei Hong ${ }^{1}$, Hao Zhang ${ }^{3}$, Xin $\mathrm{Li}^{1 *}$ and Yuelin Zhang ${ }^{1,2 *}$ \\ ${ }^{1}$ Department of Emergency Medicine, Guangdong Provincial People's Hospital, Guangdong Academy of Medical Sciences, \\ Guangzhou, China, ${ }^{2}$ The Second School of Clinical Medicine, Southern Medical University, Guangzhou, China, ${ }^{3}$ Faculty \\ of Pharmacy, Bengbu Medical College, Bengbu, China
}

Stroke, the most prevalent cerebrovascular disease, causes serious loss of neurological function and is the leading cause of morbidity and mortality worldwide. Despite advances in pharmacological and surgical therapy, treatment for functional rehabilitation following stroke is limited with a consequent serious impact on quality of life. Over the past decades, mesenchymal stem cell (MSCs)-based therapy has emerged as a novel strategy for various diseases including stroke due to their unique properties that include easy isolation, multipotent differentiation potential and strong paracrine capacity. Although MSCs have shown promising results in the treatment of stroke, there remain many challenges to overcome prior to their therapeutic application. In this review, we focus on the following issues: the scientific data from preclinical studies and clinical trials of MSCs in the treatment of stroke; the potential mechanisms underlying MSCbased therapy for stroke; the challenges related to the timing and delivery of MSCs and MSC senescence.

Keywords: mesenchymal stem cell, stroke, cell therapy, mechanisms, challenges

\section{INTRODUCTION}

Stroke, one of the major diseases of the central nervous system, is a global health problem with limited treatment options. It is classified as hemorrhagic (13\%), caused by rupture of blood vessels, or ischemic (87\%), caused by disruption of blood supply (Kalladka and Muir, 2014). With an increasing elderly population, the mortality and morbidity of stroke are increasing. Approximately 15 million individuals worldwide are affected by stroke each year, of whom 5 million will ultimately die and 5 million will suffer long-term disability (Roy-O'Reilly and McCullough, 2014). Ischemic stroke is caused by occlusion of a supply artery due to embolus or thrombus. As a result of cerebral ischemia, excitatory amino acids react with tissues and generate a large number of calcium ions and free radicals. This produces carbon monoxide with consequent irreversible necrosis of brain cells (Rastogi et al., 2006). The necrotic portion, also known as the ischemic core, is surrounded by the peri-infarct region or penumbra that represents the functionally impaired but potentially salvageable tissue and is the primary target for the developing neuroprotective strategies (Candelario-Jalil and Paul, 2021). Rapid restoration of cerebral blood flow is the focus of the treatment for acute stroke. Currently, there are no proven options for stroke patients aside from dissolution of thrombus via tissue plasminogen activator (e.g., alteplase), or mechanical thrombectomy (Hacke et al., 2008; Powers et al., 2015; Saver et al., 2016). However, thrombolysis 
has a narrow therapeutic window, being clinically effective only within $4.5 \mathrm{~h}$ after stroke and losing its effect when the thrombus is large or the stroke is extensive (Bhaskar et al., 2018). Fewer than $5 \%$ of ischemic stroke patients receive such treatment and still suffer post-treatment neurological deficits with no therapy available to promote recovery (Lyden et al., 2019). Mechanical thrombectomy exhibits the significant therapeutic efficacy in acute ischemic stroke caused by intracranial proximal artery occlusion. However, this technique is not yet fully developed, and the efficacy and safety of endovascular reperfusion beyond $6 \mathrm{~h}$ remains controversial (Berkhemer et al., 2015; Smith, 2019). Limited numbers of stroke patients can benefit from these approaches and achieve good outcomes (Detante et al., 2017).

Over the past decades, stem cell-based therapy has attracted great interest as an emerging treatment in stroke in the hope that it can repair the damaged central neural networks (Wan Safwani et al., 2017; Choi et al., 2018). Stem cell therapy displays significant effects of functional improvement for ischemic stroke, offering hope for the preservation of neural tissue in the acute phase of stroke and the replacement of lost tissue in the chronic stage (Wei et al., 2017).

MSCs are pluripotent, non-hematopoietic stem cells with the ability to differentiate into a diverse number of cell lineages, including chondrocytes, osteoblasts, and neuron-like cells (Uccelli et al., 2006; Williams and Keating, 2008). They can be isolated from almost all tissues in mammals including bone marrow (BM), adipose tissue or other tissues (Pinho et al., 2020) and are easy to culture and effectively expand. BM-MSCs are the most common, while in recent years adipose-derived MSCs have become increasingly popular due to their easy availability and high yield (Faghih et al., 2017; Perteghella et al., 2017). MSCs from bone marrow, adipose tissue have full trilineage (adipogenic, osteogenic, and chondrogenic) differentiation capacity and excellent immunomodulatory properties compared to other sources, and therefore represent the optimal stem cell sources for tissue engineering and regenerative medicine (Heo et al., 2016). Even in the acute stage of stroke, MSCs are suitable for transplantation and have substantial neurotrophic effects (Walczak et al., 2008). In addition, MSCs derived from adult tissues pose no risk of tumorigenesis and their low expression of major histocompatibility complex (MHC)-I and MHC-II antigens eliminates the need for immunosuppression following allogeneic administration (Bhatia and Hare, 2005; Williams and Hare, 2011). The therapeutic effects of MSCs are mediated by many mechanisms including anti-inflammation, anti-apoptosis, angiogenesis, and neurogenesis. They have become the focus of many preclinical and clinical studies (Li et al., 2016; Moniche et al., 2016). This review will focus on the application of MSCs in the treatment of stroke.

\section{PRECLINICAL STUDIES}

The application of MSCs in the treatment of stroke has been studied for nearly two decades. Several recent animal studies are summarized in Table 1. In most studies, Sprague Dawley
(SD) rats or Wistar rats were used to establish a model of cerebral ischemia, induced by middle cerebral artery occlusion (MCAO). It has been shown that transplantation of MSCs following ischemic stroke promotes improvement of cerebral function (Toyoshima et al., 2015; Moisan et al., 2016; Hu et al., 2019) effectively protects ischemic neurons and restores brain damage (Son et al., 2019). However, several studies used young adult and healthy animals, without taking into account the fact that a large proportion of ischemic stroke patients are elderly and the presence of comorbidities such as hypertension and diabetes (Howells et al., 2010; Laso-Garcia et al., 2019). Herein, these animal models create the barriers to the translation of the findings to clinical trials. Therefore, we here focused on studies that incorporated comorbidities into animal models of stroke.

It has been estimated that about $75 \%$ of strokes occur in the elderly (Yousufuddin and Young, 2019). Shen et al. (2007a) selected 10-12 month-old female retired breeder rats to establish an ischemic stroke model, and confirmed the longterm neurological protective effects of MSC on ischemic stroke. In addition, Saraf et al. demonstrated that stroke induced CaN hyperactivation, triggering an apoptotic pathway in neurons that further led to neuronal death in middle-aged ovariectomized female rats. MSCs treatment rescued neurons and promoted neuronal survival via reducing CaN expression (Saraf et al., 2019). Hypertension is the major risk factor for all types of stroke (Hong, 2017; Cipolla et al., 2018), Hypertensive ischemic stroke models mostly use stroke-prone spontaneously hypertensive rats (SHRSP), an animal model that develops 100\% hypertension without genetic modification, has cerebrovascular pathology and physiology very similar to that of human hypertension, and induces spontaneous strokes at a rate of more than 60\% (Liao et al., 2013). Calio et al. (2014) demonstrated that MSCs induced an increase in the anti-apoptotic gene Bcl-2 and protected brain tissue through anti-apoptosis and antioxidation, suggesting that MSCs have a protective effect on neuronal cells in SHRSP rats. In another study, placental derived MSCs treatment greatly improved functional recovery and reduced infarct size in mice with hypertensive ischemic (Kranz et al., 2010). Diabetes is a definite risk factor for stroke. Patients with diabetes have an increased probability of developing ischemic stroke, and hyperglycemia exacerbates microvascular and macrovascular damage in ischemic strokes (Rehni et al., 2017; Lau et al., 2019). Therefore, studying diabetic stroke models is of great importance. It has been reported that 6 weeks after permanent MCAO, lesions were more severe in the hyperglycemic group than in the nonhyperglycemic group. Although human adipose tissue-derived MSCs treatment for hyperglycemic stroke rats did not reduce lesion size, it significantly improved neurological function (Gomez-de Frutos et al., 2019). Cui et al. (2016) demonstrated the beneficial effects of BM- MSCs in type 1 diabetic rats with stroke via mediating miR-145. In type 2 diabetic Wistar rats with stroke, treatment with exosomes harvested from BMMSCs significantly improved blood-brain barrier (BBB) integrity, increased white matter remodeling, and promoted neural repair (Venkat et al., 2020). 
TABLE 1 | Overview of animal studies of MSC-based therapy for stroke.

\begin{tabular}{|c|c|c|c|c|c|c|c|c|}
\hline $\begin{array}{l}\text { Animal } \\
\text { species }\end{array}$ & $\begin{array}{l}\text { Stroke } \\
\text { type }\end{array}$ & Comorbidity & $\begin{array}{l}\text { Cell } \\
\text { source }\end{array}$ & Cell number & Delivery route & Timing & Results & References \\
\hline SD & MCAO & - & $\mathrm{BM}$ & $1 \times 10^{5}$ & IA (carotid artery) & 10 days & Neuronal regeneration & Hu et al., 2019 \\
\hline SD & MCAO & - & $\mathrm{BM}$ & $3 \times 10^{6}$ & IV (tail vein) & 8 days & Angiogenesis & Moisan et al., 2016 \\
\hline Wistar & MCAO & - & $\mathrm{BM}$ & $1 \times 10^{6}$ & $\mathrm{IA}$ & $\begin{array}{l}1,6,24 \\
\text { and } 48 \mathrm{~h}\end{array}$ & Reduce infarction volume & $\begin{array}{l}\text { Toyoshima et al., } \\
2015\end{array}$ \\
\hline SD & MCAO & - & $\mathrm{BM}$ & $2 \times 10^{5}$ & IC (brain tissue) & 1 days & Protect ischemic neurons & Son et al., 2019 \\
\hline Wistar & MCAO & Aging & $\mathrm{BM}$ & $2 \times 10^{6}$ & IA (carotid artery) & 1 days & $\begin{array}{l}\text { Long-term improvement in } \\
\text { functional outcome }\end{array}$ & Shen et al., 2007a \\
\hline SD & MCAO & Aging & $\mathrm{BM}$ & $1 \times 10^{5}$ & IA & $6 \mathrm{~h}$ & $\begin{array}{l}\text { Improve the functional } \\
\text { outcome }\end{array}$ & Saraf et al., 2019 \\
\hline SHR & $\begin{array}{l}\text { Stroke } \\
\text { prone }\end{array}$ & Hypertension & $\mathrm{BM}$ & $1 \times 10^{6}$ & $\begin{array}{l}\text { IC (atlanto-occipital } \\
\text { membrane) }\end{array}$ & - & $\begin{array}{l}\text { Neuroprotective and } \\
\text { antioxidant potential }\end{array}$ & Calio et al., 2014 \\
\hline SHR & MCAO & Hypertension & Placenta & $1 \times 10^{6}$ & IV (tail vein) & 8 and $24 \mathrm{~h}$ & Functional recovery & Kranz et al., 2010 \\
\hline SD & MCAO & Hyperglycemia & $\begin{array}{l}\text { Adipose } \\
\text { tissue }\end{array}$ & $1 \times 10^{6}$ & IV (tail vein) & $48 \mathrm{~h}$ & Neurological recovery & $\begin{array}{l}\text { Gomez-de Frutos } \\
\text { et al., } 2019\end{array}$ \\
\hline Wistar & MCAO & Diabetes & $\mathrm{BM}$ & $5 \times 10^{6}$ & IV (tail vein) & $24 \mathrm{~h}$ & Neurorepair effects & Cui et al., 2016 \\
\hline Wistar & MCAO & Diabetes & $\mathrm{BM}$ & $3 \times 10^{11}$ & IV (tail vein) & 3 days & $\begin{array}{l}\text { Improve the functional } \\
\text { outcome }\end{array}$ & Venkat et al., 2020 \\
\hline
\end{tabular}

MCAO, middle cerebral artery occlusion; BM, bone marrow; IA, intra-arterial; IC, intracerebral; IV, intravenous.

Comorbidities in humans can profoundly affect stroke pathophysiology, lesion development, and recovery (Cho and Yang, 2018). Despite of the beneficial effects of MSCs, more preclinical studies are warranted to exploring MSC therapy for stroke due to the limited number of relevant studies in stroke comorbidity models. Therefore, the importance of using preclinical comorbidity model should be emphasized when establishing guidelines on how to improve the validity of animal models of stroke.

\section{CLINICAL TRIALS}

Although preclinical studies have shown that MSCs displays beneficial effects on stroke (Moisan et al., 2016; Cunningham et al., 2018), the safety problems inflammation, tumor development, metastasis in clinical trials have been reported (Gazdic et al., 2015; Dhere et al., 2016; Volarevic et al., 2018). Over the past few decades, the safety, feasibility and effectiveness of MSCs in the treatment of stroke have been widely studied in clinical trials (Table 2). Previous clinical trials have shown that MSCs isolated from different tissues have shown the high efficiency for stroke treatment (Detante et al., 2017; Wechsler et al., 2018; Chrostek et al., 2019; Cui et al., 2019; Suda et al., 2020). Several routes of delivery have been proposed including intracerebral (IC), intra-arterial (IA), and intravenous (IV) (Toyoshima et al., 2017). Among them, the intracerebral pathway is the most effective and invasive route. In contrast, the intravenous pathway is the least invasive, but the number of MSC cells reaching the injured brain is the most limited. The intra-arterial pathway is relatively neutral. In 2005, autologous BMSCs transplantation was performed intravenously for the first time in five patients with acute ischemic stroke and no adverse reactions were reported (Bang et al., 2005). In 2010, a large long-term study evaluated the safety and efficacy of autologous intravenous BMSCs transplantation and got similar results (Lee et al., 2010). In 2011, the reduction in infarct lesion volume and recovery of neurological function were obtained following administration of serum-expanded autologous BMSCs to chronic stroke patients (Honmou et al., 2011). Afterwards, a phase I/II study of intracerebral cell transplantation in patients with chronic stroke has reported that intracerebral transplantation of genetically modified MSCs significantly improved neurological function (Steinberg et al., 2016, 2018). A single-center, open-label Randomized Controlled Trial study showed that intravenous injection of autologous BMSCs also improved the motor function, suggesting that MSCs treatment is feasible therapeutic strategy for stroke (Jaillard et al., 2020).

Recently, Savitz et al. (2019) conducted a randomized, sham controlled, phase II trial in which autologous BM-derived aldehyde dehydrogenase (ALDH)-bright cells were transplanted intra-arterially to patients with disabling middle cerebral artery stroke and showed no adverse events in the treatment patients group, although there was a higher incidence of small lesions on MRI. In addition, superparamagnetic iron oxide-labeled BMSCs were also used to treat stroke patients and proved to be safe and tolerated (Shichinohe et al., 2017). Compared to BMSCs, adipose tissue-derived mesenchymal stem cells (AD-MSCs) are easier and safer to prepare without adverse side effects and ethical concerns (Ra et al., 2011; Gutierrez-Fernandez et al., 2013a,b). In 2014, allogeneic intravenous AD-MSCs transplantation was carried out in patients with subacute stroke. The results demonstrated that allogeneic AD-MSCs had no association with the development of tumors. The study concluded that AD-MSCs-based cell therapy was safe and could promote rehabilitation of stroke (Diez-Tejedor et al., 2014).

Human umbilical cord-derived MSCs (hUC-MSCs) have great advantages for stroke treatment due to low immunogenicity and no substantial ethical problems (Yin et al., 2019). A Phase 
TABLE 2 | Clinical trials of MSC-based therapy for stroke.

\begin{tabular}{|c|c|c|c|c|c|c|c|}
\hline Phase & $\begin{array}{l}\text { Patients } \\
\text { number }\end{array}$ & $\begin{array}{l}\text { Delivery } \\
\text { route }\end{array}$ & Cell source & Cell number & Timing & Results & References \\
\hline I & 5 & IV & Autologous BM-MSCs & $1 \times 10^{8}$ & 7 days & Improve in $\mathrm{Bl}$ & Bang et al., 2005 \\
\hline$\|$ & 16 & IV & Autologous BM-MSCs & $5 \times 10^{7}$ & 5-7 weeks & Improve in $\mathrm{mRS}$ & Lee et al., 2010 \\
\hline I & 12 & IV & Autologous BM-MSCs & $1 \times 10^{8}$ & 36-133 days & Improve in NIHSS & $\begin{array}{l}\text { Honmou et al., } \\
2011\end{array}$ \\
\hline I & 8 & IV & Autologous BM-MSCs & $5-6 \times 10^{7}$ & 3 months -1 year & $\begin{array}{l}\text { Improve in Fugle-Meyer } \\
\text { and mRS, increase in } \\
\text { number of cluster activation } \\
\text { of Brodmann areas BA } 4 \\
\text { and BA } 6\end{array}$ & Bhasin et al., 2011 \\
\hline$\|$ & 20 & IV & Allogeneic AD-MSCs & $1 \times 10^{6}$ cells $/ \mathrm{kg}$ & 2 week & Safe and effective & $\begin{array}{l}\text { Diez-Tejedor et al., } \\
2014\end{array}$ \\
\hline l/lla & 18 & IC & $\begin{array}{l}\text { Modified MSCs } \\
\text { (SB623) }\end{array}$ & $\begin{array}{l}\text { dose-escalation: } \\
2.5 \times 10^{6}, 5.0 \times 10^{6}, \\
\text { or } 10 \times 10^{6}\end{array}$ & 6-60 months & $\begin{array}{l}\text { improve in } \\
\text { ESS,NIHSS,Fugle-Meyer }\end{array}$ & $\begin{array}{l}\text { Steinberg et al., } \\
2016,2018\end{array}$ \\
\hline$\|$ & 48 & $\mathrm{IA}$ & BM-ALDH ${ }^{b r}$ cells & $0.5 \times 10^{5}-2.5 \times 10^{7}$ & $9-15$ days & Safe & Savitz et al., 2019 \\
\hline । & 10 & IV & Allogeneic UC-MSCs & $5 \times 10^{6}-5 \times 10^{7} / \mathrm{Kg}$ & $7-10$ days & Safe and feasible & $\begin{array}{l}\text { Laskowitz et al., } \\
2018\end{array}$ \\
\hline$\|$ & 16 & IV & Autologous BM-MSCs & $10 \times 10^{7}-30 \times 10^{7}$ & 14 days & $\begin{array}{l}\text { Improve in } \\
\text { motor-NIHSS,Fugle-Meyer, } \\
\text { task-related fMRI activity }\end{array}$ & Jaillard et al., 2020 \\
\hline
\end{tabular}

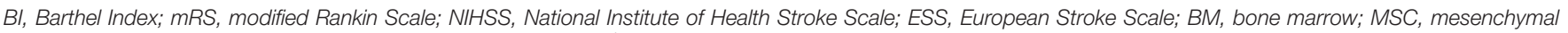
stem cell; UC-MSC, umbilical cord mesenchymal stem cell; $A L D H^{\text {br }}$, aldehyde dehydrogenase bright; IA, intra-arterial; IC, intracerebral; IV, intravenous.

I clinical trial using hUC-MSCs for acute stroke treatment demonstrated a significant functional recovery, indicating that hUC-MSCs treatment is safe and feasible option for acute stroke (Laskowitz et al., 2018).

Although MSC transplantation has been proven to be safe and feasible in small phase I/II trials, no significant improvement was observed in a randomized controlled intravenous phase II trial (Hess et al., 2017). Their efficacy in the treatment of ischemic stroke therefore remains controversial (Hess et al., 2017). Several reasons are proposed for the inconsistent results of MSC transplantation in ischemic stroke. First, trials differ in patient numbers, dose and type of cell delivery, timing of cell therapy, and treatment modalities. Second, the location/extent and severity of the lesions are different. The studies also applied different evaluation criteria when assessing neurological function and adverse reactions. More optimized and well-designed large sample multicenter studies are needed to explore the therapeutic efficacy of MSCs in ischemic stroke.

\section{POTENTIAL MECHANISMS OF MSC THERAPY FOR STROKE}

Currently, the underlying mechanisms of MSC-based therapy for stroke have not been fully elucidated. Many experimental studies have revealed that MSCs protect against stroke through multiple mechanisms including direct differentiation, paracrine effects and mitochondrial transfer (Figure 1).

\section{MSC Differentiation}

MSCs are pluripotent adult mesenchymal cells with the ability of self-renewal and multi-differentiation (Klimczak and Kozlowska,
2016). In the presence of injury and inflammation, MSCs are directly transplanted or homed to the damaged site (Shi et al., 2012). In a specific microenvironment of a tissue or organ, MSCs have the ability to divide and proliferate, differentiate and develop into the same cell type as the tissue or organ, including neuronal cells, and effect repair (Clevers et al., 2014; Shi et al., 2016). It has been reported that MSCs isolated from human umbilical cord can differentiate into neuron-like cells and maintain their immunomodulatory and antioxidant activities (Li et al., 2012).

\section{Paracrine Effects}

There is accumulating evidence that the ability of MSCs to differentiate into neuron cells cannot on its own explain the predominant benefits of MSC-based therapy (Ghittoni et al., 2005; Wang et al., 2012; Bang and Kim, 2019; Brown et al., 2020). Compared with BM-MSC transplantation, infusion of MSC-derived conditioned medium has been shown to equally improve injured brain function (Ghittoni et al., 2005; Gnecchi et al., 2006; Volarevic et al., 2011). A paracrine effect of MSCs is thus concluded to be a major mechanism underlying the benefits of MSC-based therapy for stroke (Liang et al., 2014). There is a close interaction between the soluble factors derived from MSCs and immune cells (such as dendritic cells, lymphocytes, natural killer cells, and macrophages) (Gao et al., 2014). A paracrine role is reflected in immune regulation: MSCs secrete soluble factors through direct cell-cell interaction, are involved in immune regulation and induce immune tolerance, and can improve and regulate the destructive inflammatory response (Wu et al., 2017; de Witte et al., 2018). Numerous paracrine components form a complex exocrine factor network to ensure the stability of cells and enhance the regeneration response. Many MSC-based tissue repair models are largely 


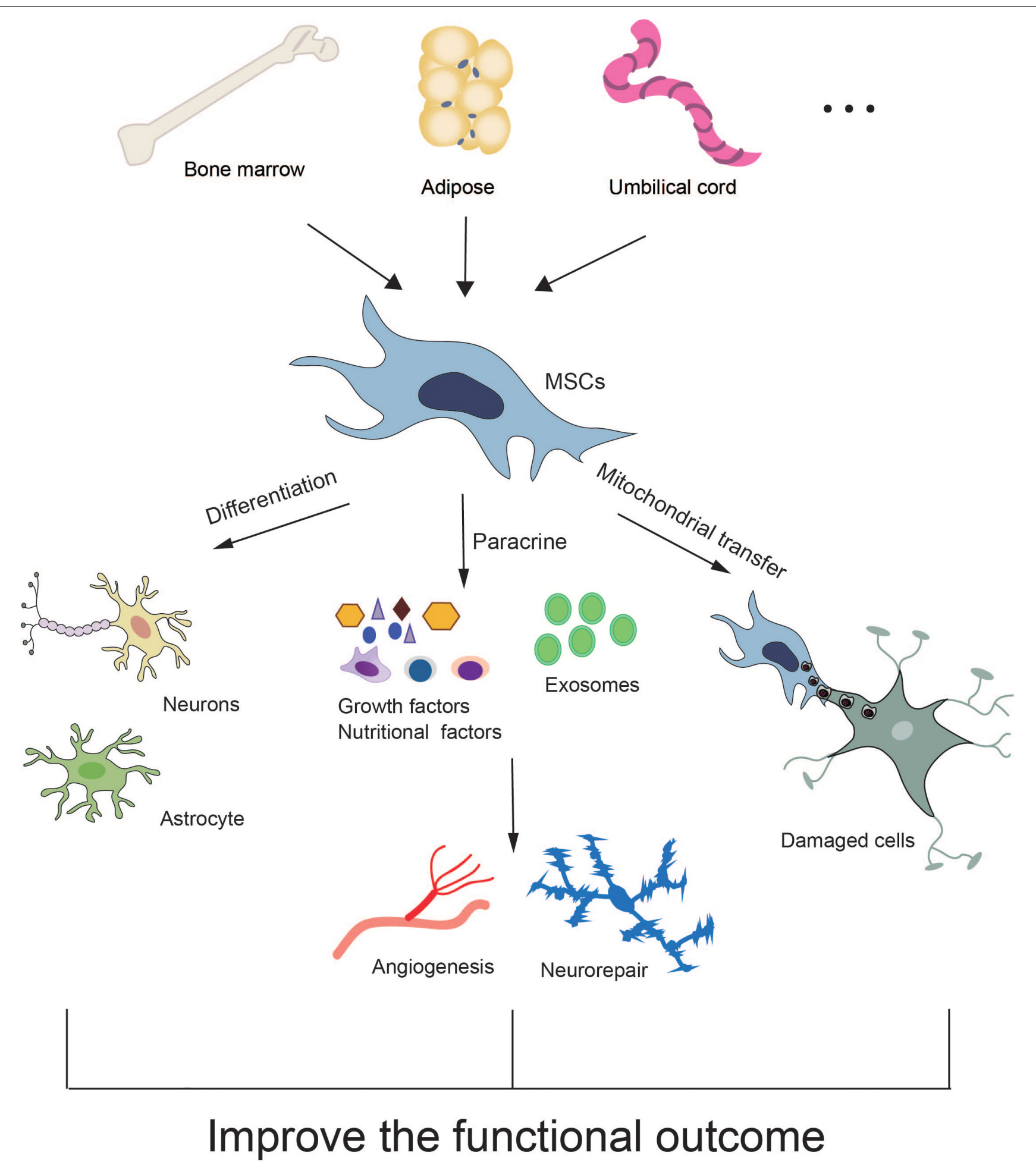

FIGURE 1 | Potential mechanisms of MSC therapy for stroke.

dependent on the paracrine action of MSCs (Weiss and Dahlke, 2019; Wu et al., 2020). Another manifestation of their paracrine effect is in the promotion of angiogenesis (De Luca et al., 2011; Gnecchi et al., 2016; Chen et al., 2020). Both basic fibroblast growth factor and vascular endothelial growth factor induce endothelial cell proliferation and migration to form new vascular branches from existing vascular branches (Gnecchi et al., 2006). The various nutritional factors secreted 
by MSCs, including enzymes, growth factors, chemokines, matrix metalloproteinases, and adhesion molecules, all have an effect on several key steps of angiogenesis. They can induce the proliferation, migration and tubular formation of vascular endothelial cells, as well as inhibit apoptosis of endothelial cells (Kinnaird et al., 2004; Rehman et al., 2004). Transplantation of adipose tissue-derived MSCs has also been shown to promote angiogenesis and improve behavioral recovery in SD rats after MCAO operation (Mu et al., 2019). BM-MSCs can increase the expression of astrocyte-derived VEGF and BDNF in the ischemic boundary zone after stroke and promote angiogenesis, as well as the recruitment and proliferation of reactive astrocytes, leading to nerve injury repair (Guo et al., 2012; Zhang et al., 2017). Moreover, Human BM-MSCs have been shown to increase cerebral vascular generation in stroke lesions by releasing endogenous angiogenic factors that enhance the stability of new blood vessels (Moisan et al., 2016). Therefore, the paracrine effect of stem cells is likely to play an important role in increasing capillary density and angiogenesis in the damaged brain.

Notably, exosomes are the most important agents in the process of information transmission and inducing repair for many secreted cytokines (Elahi et al., 2020). The paracrine effect produced by their external secretion plays a critical role in stroke recovery (Xin et al., 2013a; Hao et al., 2014; Zhang Y. et al., 2015; Zhang et al., 2019). Exosomes from MSCs are 30-100 nm diameter lipid particles with a double membrane structure containing micro RNAs, mRNAs, DNAs, and bioactive substances such as protein and lipids. They display similar properties and functions to MSCs including low immunogenicity and the ability to stimulate nerve vascular repair with no risk of tumor formation (Yaghoubi et al., 2019). Increasing lines of evidence have confirmed that exosomes contribute significantly to the benefits of cell-based therapies, including the treatment of stroke, traumatic brain injury and other neurological diseases (Xin et al., 2013b; Zhang Y. et al., 2015; Stonesifer et al., 2017; Zhang et al., 2019). Dabrowska et al. (2019) demonstrated that intra-arterial delivery of exosomes derived from BM-MSCs reduced neuroinflammation induced by focal brain injury in ischemic stroke and this effect was comparable with that of transplanted BM-MSCs. In some mouse models of stroke, the long-term neuroprotection afforded by MSCs was closely associated with enhanced angiogenesis, and reduced postischemic immunosuppression (i.e., B cells, natural killer cells, and T-cell lymphocytosis), providing an appropriate external environment for successful brain remodeling (Doeppner et al., 2015; Hu et al., 2016). The secretion of a wide range of bioactive molecules is now considered the major mechanism of MSCbased therapy.

\section{Mitochondrial Transfer}

Mitochondrial transfer is a novel mechanism for stem cell therapy that has attracted wide attention. MSCs can transfer mitochondria to injured cells with mitochondrial dysfunction through a variety of ways to restore cell aerobic respiration and mitochondria function, leading to rescue of cell injury (Spees et al., 2006; Islam et al., 2012; Han et al., 2016). Mitochondrial dysfunction has been considered a sign of ischemia/reperfusion injury in the complex cell process, so mitochondrial transfer may be one of the mechanisms by which MSC treatment is of benefit for stroke (Han et al., 2020). Co-cultured BM-MSCs can transfer intact mitochondria through transient tunneling nanotubes (TNT) to damaged cells, restoring their mitochondrial function (Han et al., 2016). Yang et al. demonstrated that iPSC-MSCs could protect damaged PC12 cells by restoring mitochondrial function. This was not just due to the paracrine effect of MSCs, but also attributed to the mitochondria transferred from MSCs to the injured PC12 cells (Yang et al., 2020). There is accumulating evidence that mitochondrial transfer between MSCs and damaged cells is mainly mediated through tunneled nanotubes and microvesicles (Spees et al., 2006; Islam et al., 2012; Li et al., 2014; Murray and Krasnodembskaya, 2019). In addition, Babenko et al. (2015) reported that BM-MSCs can donate mitochondria to injured astrocytes and restore their mitochondrial function, demonstrating the protective function of MSCs on nerves. Tseng et al. (2020) demonstrated that transfer of mitochondria from MSCs to damaged neurons induced by oxidative stress in vivo and in vitro resulted in metabolic benefits. The researchers tagged BM-MSCs and tracked the transplanted mitochondria. They observed the mitochondria transfer and a protective effect on the damaged cerebral microvascular system in rats with cerebral ischemia (Liu et al., 2019; Yang et al., 2020). Thus, mitochondrial transfer from MSCs to damaged cells may offer a new avenue in the treatment of stroke.

\section{CHALLENGES OF MSC THERAPY FOR STROKE}

Although many animal studies and clinical trials of MSC-based therapy for stroke have obtained promising results, there remain many challenges to overcome before MSCs can be widely applied in clinical practice.

First, the optimum time for MSC administration remains controversial. Currently, most preclinical studies recommend transplanting MSCs during the acute stroke stage ( $<48 \mathrm{~h})$. It has been reported that stroke can cause an increase in reactive oxygen species, activation of immune cells and production of pro-inflammatory cytokines in the acute phase, thus aggravating the secondary brain injury. MSC exosomes display immunomodulatory and neuroprotective effects, especially in the acute phase of stroke (Tobin et al., 2014; Vu et al., 2014). In contrast, some studies have shown that administration of MSCs in rats 1 month after stroke could also lead to neurological recovery (Shen et al., 2007b). MSCs can secrete many growth factors to activate the endogenous repair process, induce a decrease in glial scar and increase proliferation of cells in the subventricular area, promoting neurogenesis in the chronic phase of stroke (Shen et al., 2007b; Sinden et al., 2012). MSC transplantation has also been administered in the subacute or chronic stage of stroke in some clinical studies (Lalu et al., 2020). How to solve this knowledge gap and use available evidence to determine the optimal timing for cell therapy remains a major challenge. 
Another challenge is to determine the best treatment. Although MSCs have shown general immune evasion and tolerance in clinical studies of stroke, an increasing number of preclinical studies have proved the therapeutic efficacy of conditioned medium (CM) and extracellular vesicles (EVs) derived from MSCs that reduces the dependence on and need for cells (Xin et al., 2013b; Cunningham et al., 2018). These cellfree substitutes can be cryopreserved with no concerns about cell survival. Cells can be preserved for a long time and transported around the world. Nevertheless, there is no clear consensus on the optimal culture conditions and pretreatment strategies to maximize the regenerative potential of MSC-derived CM or EVs (Reiner et al., 2017). Further clinical studies are needed to clarify their therapeutic value for stroke.

Third, the route of MSC administration is another major challenge. Previous studies have used both systemic and direct approaches such as IV, IA, and IC. Compared with more invasive routes (e.g., intrathecal and IC approaches), minimally invasive routes (e.g., IV and IA approaches) may cause less damage at the injection site although each route has its own advantages and disadvantages. How to choose a simpler and safer delivery route for MSCs is a major hurdle to their clinical application with much greater care required by the clinician.

Fourth, the best source of MSCs for stroke treatment has not been determined. Although most preclinical studies (>90\%) use fresh MSCs from healthy, young donors, half of the clinical studies used autologous MSC products. Autologous MSCs may circumvent the logistical ethical problems and have been proven to be more effective than those obtained from healthy donors (Block et al., 2017; van de Vyver, 2017). Nonetheless, expanding enough stem cells for transplantation requires a long time, so it is impossible to use autologous MSC cells in the acute stage of stroke, especially from elderly patients or those with serious diseases. Genetic engineering or reprogramming to amplify MSCs can lead to uncontrolled proliferation and genetic abnormality, limiting their viability and therapeutic potential (Zhang J. et al., 2015). Furthermore, whether modified MSCs can successfully differentiate into fully functional neural cells in patients remains elusive (Strioga et al., 2012). One large randomized controlled clinical trial reported that cryopreserved allogeneic MSCs from healthy donors had poor viability and poor clinical efficacy (Matthay et al., 2019). Therefore, when using allogeneic cells from healthy donors care should be taken to assess their viability in order to match preclinical conditions.

Fifth, another challenge is the heterogeneity in study designs. The poor methodological rigorism of both preclinical and clinical studies may have contributed to the current conflicting results. Preclinical studies rarely adopted randomized or blinding designs, or carried out confirmatory studies, a pre-requisite of clinical trials (Macleod et al., 2008; Hirst et al., 2014). Similar problems also existed in clinical studies. Studies included RCT (Lee et al., 2010; Hess et al., 2017), single-arm trial (Steinberg et al., 2016), or case series (Honmou et al., 2011), and could not be compared. Previous clinical measures of efficacy reported included NIHSS, mRS, BI, Fugle-Meyer scale, and ESS. A unified method for evaluation of neurological function is lacking so it is difficult to reach a consistent conclusion about the safety and effectiveness of MSCs in clinical application. How to increase methodological rigorism is a great challenge for preclinical and clinical studies.

Sixth, senescence of MSCs has attracted extensive attention in recent years. The passage times of MSCs are limited. Extension of expansion time will inevitably lead to replicative senescence. Moreover, MSCs isolated from the elderly exhibit an aging phenotype with a decline in function, leading to decreased therapeutic efficacy (Wagner et al., 2008). Therefore, developing strategies to deal with MSC senescence is another future challenge (Kim and Park, 2017).

Finally,the comorbidities of patients are also the challenges for MSC therapy (Cui et al., 2019). Many stroke patients have comorbidities such as hypertension, diabetes and heart disease that may exert an impact on therapy efficacy (Chen et al., 2011). The medications such as antidiabetics and antiplatelet drugs often influence MSC function, limiting the therapeutic effects (Ortega et al., 2013). Unfortunately, most of preclinical studies haven't investigated influence factors, leading to a big knowledge gap in translate stroke research to clinic.

\section{CONCLUSION}

MSCs have many advantages: they are immune evasive, easy to harvest, expand and store for a long time, and convenient to manage in various ways. Additionally, their clinical use does not raise many ethical issues. Increasing evidence supports the potential of MSCs to treat stroke, but there are challenges to overcome. We have systematically reviewed the safety and efficacy of MSCs in the treatment of ischemic stroke and hemorrhagic stroke. In preclinical studies, MSC treatment has shown considerable efficacy in some neurological function tests, but there remains no large-scale randomized, double-blind, multicenter clinical study to prove their effectiveness. The heterogeneity of MSCs is the main barrier to their clinical application and therapeutic effect. Key parameters such as the source of MSCs, dosage, route of administration, administration time and other key parameters directly affect the application effect. More importantly, many clinical trials have similar limitations in detecting the role of MSCs, including small size, lack of a control arm, and inconsistent methods for use of MSCs. Homogenization and quality control are key issues in their clinical application. Future preclinical and clinical studies should consider adoption of a well-designed randomized controlled study design, method rigor and intervention measures, so as to determine the effect of MSC therapy in the treatment of stroke (Napoli and Borlongan, 2016; Squillaro et al., 2016). Nonetheless, despite these issues, MSCs have exciting potential as a means to protect neurons and improve the outcome for stroke patients.

\section{AUTHOR CONTRIBUTIONS}

WL and LS searched the literature and wrote the manuscript. $\mathrm{BH}$, $\mathrm{YH}$, and $\mathrm{HZ}$ searched the literature and provided comments. XL and YZ designed the study and wrote the manuscript. All authors contributed to the article and approved the submitted version. 


\section{FUNDING}

This research was supported in part by the High-level Hospital Construction Project of Guangdong Provincial People's Hospital
(DFJH201918 to YZ, DFJH2020020 to WL), and a grant from the Science and Technology Planning Project of Guangzhou (201804010335 to BH) and Tibet Autonomous Region Research Projects (XZ2018-01-GB-09 to XL).

\section{REFERENCES}

Babenko, V. A., Silachev, D. N., Zorova, L. D., Pevzner, I. B., Khutornenko, A. A., Plotnikov, E. Y., et al. (2015). Improving the post-stroke therapeutic potency of mesenchymal multipotent stromal cells by cocultivation with cortical neurons: the role of crosstalk between cells. Stem Cells Transl. Med. 4, 1011-1020. doi: 10.5966/sctm.2015-0010

Bang, O. Y., and Kim, E. H. (2019). Mesenchymal stem cell-derived extracellular vesicle therapy for stroke: challenges and progress. Front. Neurol. 10:211. doi: 10.3389/fneur.2019.00211

Bang, O. Y., Lee, J. S., Lee, P. H., and Lee, G. (2005). Autologous mesenchymal stem cell transplantation in stroke patients. Ann. Neurol. 57, 874-882. doi: 10.1002/ana.20501

Berkhemer, O. A., Fransen, P. S., Beumer, D., van den Berg, L. A., Lingsma, H. F., Yoo, A. J., et al. (2015). A randomized trial of intraarterial treatment for acute ischemic stroke. N. Engl. J. Med. 372, 11-20. doi: 10.1056/NEJMoa 1411587

Bhasin, A., Srivastava, M. V. P., Kumaran, S. S., Mohanty, S., Bhatia, R., Bose, S., et al. (2011). Autologous mesenchymal stem cells in chronic stroke. Cerebrovasc. Dis. Extra 1, 93-104. doi: 10.1159/000333381

Bhaskar, S., Stanwell, P., Cordato, D., Attia, J., and Levi, C. (2018). Reperfusion therapy in acute ischemic stroke: dawn of a new era? BMC Neurol. 18:8. doi: 10.1186/s12883-017-1007-y

Bhatia, R., and Hare, J. M. (2005). Mesenchymal stem cells: future source for reparative medicine. Congest. Heart Fail. 11, 87-91. doi: 10.1111/j.1527-5299. 2005.03618.x quiz 92-83,

Block, T. J., Marinkovic, M., Tran, O. N., Gonzalez, A. O., Marshall, A., Dean, D. D., et al. (2017). Restoring the quantity and quality of elderly human mesenchymal stem cells for autologous cell-based therapies. Stem Cell Res. Ther. 8:239. doi: 10.1186/s13287-017-0688-x

Brown, J., Park, Y. J., Lee, J. Y., Chase, T. N., Koga, M., and Borlongan, C. V. (2020). Bone marrow-derived NCS-01 cells advance a novel cellbased therapy for stroke. Int. J. Mol. Sci. 21:2845. doi: 10.3390/ijms210 82845

Calio, M. L., Marinho, D. S., Ko, G. M., Ribeiro, R. R., Carbonel, A. F., Oyama, L. M., et al. (2014). Transplantation of bone marrow mesenchymal stem cells decreases oxidative stress, apoptosis, and hippocampal damage in brain of a spontaneous stroke model. Free Radic. Biol. Med. 70, 141-154. doi: 10.1016/j. freeradbiomed.2014.01.024

Candelario-Jalil, E., and Paul, S. (2021). Impact of aging and comorbidities on ischemic stroke outcomes in preclinical animal models: a translational perspective. Exp. Neurol. 335:113494. doi: 10.1016/j.expneurol.2020.113494

Chen, J., Ye, X., Yan, T., Zhang, C., Yang, X. P., Cui, X., et al. (2011). Adverse effects of bone marrow stromal cell treatment of stroke in diabetic rats. Stroke 42, 3551-3558. doi: 10.1161/STROKEAHA.111.627174

Chen, L., Wang, Y., Li, S., Zuo, B., Zhang, X., Wang, F., et al. (2020). Exosomes derived from GDNF-modified human adipose mesenchymal stem cells ameliorate peritubular capillary loss in tubulointerstitial fibrosis by activating the SIRT1/eNOS signaling pathway. Theranostics 10, 9425-9442. doi: $10.7150 /$ thno. 43315

Cho, S., and Yang, J. (2018). What do experimental models teach us about comorbidities in stroke? Stroke 49, 501-507. doi: 10.1161/STROKEAHA.117. 017793

Choi, J. R., Yong, K. W., and Choi, J. Y. (2018). Effects of mechanical loading on human mesenchymal stem cells for cartilage tissue engineering. J. Cell. Physiol. 233, 1913-1928. doi: 10.1002/jcp.26018

Chrostek, M. R., Fellows, E. G., Crane, A. T., Grande, A. W., and Low, W. C. (2019). Efficacy of stem cell-based therapies for stroke. Brain Res. 1722:146362. doi: 10.1016/j.brainres.2019.146362

Cipolla, M. J., Liebeskind, D. S., and Chan, S. L. (2018). The importance of comorbidities in ischemic stroke: impact of hypertension on the cerebral circulation. J. Cereb. Blood Flow Metab. 38, 2129-2149. doi: 10.1177/ 0271678X18800589

Clevers, H., Loh, K. M., and Nusse, R. (2014). Stem cell signaling. An integral program for tissue renewal and regeneration: Wnt signaling and stem cell control. Science 346:1248012. doi: 10.1126/science.12 48012

Cui, C., Ye, X., Chopp, M., Venkat, P., Zacharek, A., Yan, T., et al. (2016). miR-145 regulates diabetes-bone marrow stromal cell-induced neurorestorative effects in diabetes stroke rats. Stem Cells Transl. Med. 5, 1656-1667. doi: 10.5966/sctm. 2015-0349

Cui, L. L., Golubczyk, D., Tolppanen, A. M., Boltze, J., and Jolkkonen, J. (2019). Cell therapy for ischemic stroke: are differences in preclinical and clinical study design responsible for the translational loss of efficacy? Ann. Neurol. 86, 5-16. doi: 10.1002/ana.25493

Cunningham, C. J., Redondo-Castro, E., and Allan, S. M. (2018). The therapeutic potential of the mesenchymal stem cell secretome in ischaemic stroke. J. Cereb. Blood Flow Metab. 38, 1276-1292. doi: 10.1177/0271678X18 776802

Dabrowska, S., Andrzejewska, A., Strzemecki, D., Muraca, M., Janowski, M., and Lukomska, B. (2019). Human bone marrow mesenchymal stem cellderived extracellular vesicles attenuate neuroinflammation evoked by focal brain injury in rats. J. Neuroinflammation 16:216. doi: 10.1186/s12974-01 9-1602-5

De Luca, A., Gallo, M., Aldinucci, D., Ribatti, D., Lamura, L., D’Alessio, A., et al. (2011). Role of the EGFR ligand/receptor system in the secretion of angiogenic factors in mesenchymal stem cells. J. Cell Physiol. 226, 2131-2138. doi: 10.1002/ jcp. 22548

de Witte, S. F. H., Luk, F., Sierra Parraga, J. M., Gargesha, M., Merino, A., Korevaar, S. S., et al. (2018). Immunomodulation by therapeutic mesenchymal stromal cells (MSC) is triggered through phagocytosis of MSC by monocytic cells. Stem Cells 36, 602-615. doi: 10.1002/stem.2779

Detante, O., Moisan, A., Hommel, M., and Jaillard, A. (2017). Controlled clinical trials of cell therapy in stroke: meta-analysis at six months after treatment. Int. J. Stroke 12, 748-751. doi: 10.1177/1747493017696098

Dhere, T., Copland, I., Garcia, M., Chiang, K. Y., Chinnadurai, R., Prasad, M., et al. (2016). The safety of autologous and metabolically fit bone marrow mesenchymal stromal cells in medically refractory Crohn's disease - a phase 1 trial with three doses. Aliment. Pharmacol. Ther. 44, 471-481. doi: 10.1111/ apt.13717

Diez-Tejedor, E., Gutierrez-Fernandez, M., Martinez-Sanchez, P., RodriguezFrutos, B., Ruiz-Ares, G., Lara, M. L., et al. (2014). Reparative therapy for acute ischemic stroke with allogeneic mesenchymal stem cells from adipose tissue: a safety assessment: a phase II randomized, doubleblind, placebo-controlled, single-center, pilot clinical trial. J. Stroke Cerebrovasc. Dis. 23, 2694-2700. doi: 10.1016/j.jstrokecerebrovasdis.2014. 06.011

Doeppner, T. R., Herz, J., Gorgens, A., Schlechter, J., Ludwig, A. K., Radtke, S., et al. (2015). Extracellular vesicles improve post-stroke neuroregeneration and prevent postischemic immunosuppression. Stem Cells Transl. Med. 4, 1131-1143. doi: 10.5966/sctm.20 15-0078

Elahi, F. M., Farwell, D. G., Nolta, J. A., and Anderson, J. D. (2020). Preclinical translation of exosomes derived from mesenchymal stem/stromal cells. Stem Cells 38, 15-21. doi: 10.1002/stem.3061

Faghih, H., Javeri, A., and Taha, M. F. (2017). Impact of early subcultures on stemness, migration and angiogenic potential of adipose tissue-derived stem cells and their resistance to in vitro ischemic condition. Cytotechnology 69, 885-900. doi: 10.1007/s10616-017-0104-5

Gao, S., Mao, F., Zhang, B., Zhang, L., Zhang, X., Wang, M., et al. (2014). Mouse bone marrow-derived mesenchymal stem cells induce macrophage M2 polarization through the nuclear factor-kappaB 
and signal transducer and activator of transcription 3 pathways. Exp. Biol. Med. (Maywood) 239, 366-375. doi: 10.1177/15353702135 18169

Gazdic, M., Volarevic, V., Arsenijevic, N., and Stojkovic, M. (2015). Mesenchymal stem cells: a friend or foe in immune-mediated diseases. Stem Cell Rev. Rep. 11, 280-287. doi: 10.1007/s12015-014-9583-3

Ghittoni, R., Patrussi, L., Pirozzi, K., Pellegrini, M., Lazzerini, P. E., Capecchi, P. L., et al. (2005). Simvastatin inhibits T-cell activation by selectively impairing the function of Ras superfamily GTPases. FASEB J. 19, 605-607. doi: 10.1096/fj.042702fje

Gnecchi, M., Danieli, P., Malpasso, G., and Ciuffreda, M. C. (2016). Paracrine mechanisms of mesenchymal stem cells in tissue repair. Methods Mol. Biol. 1416, 123-146. doi: 10.1007/978-1-4939-3584-0_7

Gnecchi, M., He, H., Noiseux, N., Liang, O. D., Zhang, L., Morello, F., et al. (2006). Evidence supporting paracrine hypothesis for Akt-modified mesenchymal stem cell-mediated cardiac protection and functional improvement. FASEB J. 20, 661-669. doi: 10.1096/fj.05-5211com

Gomez-de Frutos, M. C., Laso-Garcia, F., Diekhorst, L., Otero-Ortega, L., Fuentes, B., Jolkkonen, J., et al. (2019). Intravenous delivery of adipose tissue-derived mesenchymal stem cells improves brain repair in hyperglycemic stroke rats. Stem Cell Res. Ther. 10:212. doi: 10.1186/s13287-01 9-1322-x

Guo, F., Lv, S., Lou, Y., Tu, W., Liao, W., Wang, Y., et al. (2012). Bone marrow stromal cells enhance the angiogenesis in ischaemic cortex after stroke: involvement of notch signalling. Cell Biol. Int. 36, 997-1004. doi: 10.1042/ CBI20110596

Gutierrez-Fernandez, M., Rodriguez-Frutos, B., Otero-Ortega, L., Ramos-Cejudo, J., Fuentes, B., and Diez-Tejedor, E. (2013a). Adipose tissue-derived stem cells in stroke treatment: from bench to bedside. Discov. Med. 16, 37-43.

Gutierrez-Fernandez, M., Rodriguez-Frutos, B., Ramos-Cejudo, J., Teresa VallejoCremades, M., Fuentes, B., Cerdan, S., et al. (2013b). Effects of intravenous administration of allogenic bone marrow- and adipose tissue-derived mesenchymal stem cells on functional recovery and brain repair markers in experimental ischemic stroke. Stem Cell Res. Ther. 4:11. doi: 10.1186/ scrt159

Hacke, W., Kaste, M., Bluhmki, E., Brozman, M., Davalos, A., Guidetti, D., et al. (2008). Thrombolysis with alteplase 3 to 4.5 hours after acute ischemic stroke. N. Engl. J. Med. 359, 1317-1329. doi: 10.1056/NEJMoa0804656

Han, D., Zheng, X., Wang, X., Jin, T., Cui, L., and Chen, Z. (2020). Mesenchymal stem/stromal cell-mediated mitochondrial transfer and the therapeutic potential in treatment of neurological diseases. Stem Cells Int. 2020:8838046. doi: 10.1155/2020/8838046

Han, H., Hu, J., Yan, Q., Zhu, J., Zhu, Z., Chen, Y., et al. (2016). Bone marrowderived mesenchymal stem cells rescue injured $\mathrm{H} 9 \mathrm{c} 2$ cells via transferring intact mitochondria through tunneling nanotubes in an in vitro simulated ischemia/reperfusion model. Mol. Med. Rep. 13, 1517-1524. doi: 10.3892/mmr. 2015.4726

Hao, L., Zou, Z., Tian, H., Zhang, Y., Zhou, H., and Liu, L. (2014). Stem cell-based therapies for ischemic stroke. Biomed. Res. Int. 2014:468748. doi: 10.1155/2014/ 468748

Heo, J. S., Choi, Y., Kim, H. S., and Kim, H. O. (2016). Comparison of molecular profiles of human mesenchymal stem cells derived from bone marrow, umbilical cord blood, placenta and adipose tissue. Int. J. Mol. Med. 37, 115-125. doi: 10.3892/ijmm.2015.2413

Hess, D. C., Wechsler, L. R., Clark, W. M., Savitz, S. I., Ford, G. A., Chiu, D., et al. (2017). Safety and efficacy of multipotent adult progenitor cells in acute ischaemic stroke (MASTERS): a randomised, double-blind, placebo-controlled, phase 2 trial. Lancet Neurol. 16, 360-368. doi: 10.1016/S1474-4422(17) 30046-7

Hirst, J. A., Howick, J., Aronson, J. K., Roberts, N., Perera, R., Koshiaris, C., et al. (2014). The need for randomization in animal trials: an overview of systematic reviews. PLoS One 9:e98856. doi: 10.1371/journal.pone.00 98856

Hong, K. S. (2017). Blood pressure management for stroke prevention and in acute stroke. J. Stroke 19, 152-165. doi: 10.5853/jos.2017. 00164

Honmou, O., Houkin, K., Matsunaga, T., Niitsu, Y., Ishiai, S., Onodera, R., et al. (2011). Intravenous administration of auto serum-expanded autologous mesenchymal stem cells in stroke. Brain 134, 1790-1807. doi: 10.1093/brain/ awr063

Howells, D. W., Porritt, M. J., Rewell, S. S., O'Collins, V., Sena, E. S., van der Worp, H. B., et al. (2010). Different strokes for different folks: the rich diversity of animal models of focal cerebral ischemia. J. Cereb. Blood Flow Metab. 30, 1412-1431. doi: 10.1038/jcbfm. 2010.66

Hu, B., Chen, S., Zou, M., He, Z., Shao, S., and Liu, B. (2016). Effect of extracellular vesicles on neural functional recovery and immunologic suppression after rat cerebral apoplexy. Cell. Physiol. Biochem. 40, 155-162. doi: 10.1159/0004 52533

Hu, Y., Chen, W., Wu, L., Jiang, L., Qin, H., and Tang, N. (2019). Hypoxic preconditioning improves the survival and neural effects of transplanted mesenchymal stem cells via CXCL12/CXCR4 signalling in a rat model of cerebral infarction. Cell Biochem. Funct. 37, 504-515. doi: 10.1002/ cbf. 3423

Islam, M. N., Das, S. R., Emin, M. T., Wei, M., Sun, L., Westphalen, K., et al. (2012). Mitochondrial transfer from bone-marrow-derived stromal cells to pulmonary alveoli protects against acute lung injury. Nat. Med. 18, 759-765. doi: $10.1038 / \mathrm{nm} .2736$

Jaillard, A., Hommel, M., Moisan, A., Zeffiro, T. A., Favre-Wiki, I. M., BarbieuxGuillot, M., et al. (2020). Autologous mesenchymal stem cells improve motor recovery in subacute ischemic stroke: a randomized clinical trial. Transl. Stroke Res. 11, 910-923. doi: 10.1007/s12975-020-00787-z

Kalladka, D., and Muir, K. W. (2014). Brain repair: cell therapy in stroke. Stem Cells Cloning 7, 31-44. doi: 10.2147/SCCAA.S38003

Kim, H. J., and Park, J. S. (2017). Usage of human mesenchymal stem cells in cell-based therapy: advantages and disadvantages. Dev. Reprod. 21, 1-10. doi: 10.12717/DR.2017.21.1.001

Kinnaird, T., Stabile, E., Burnett, M. S., Lee, C. W., Barr, S., Fuchs, S., et al. (2004). Marrow-derived stromal cells express genes encoding a broad spectrum of arteriogenic cytokines and promote in vitro and in vivo arteriogenesis through paracrine mechanisms. Circ. Res. 94, 678-685. doi: 10.1161/01.RES.0000118601. 37875.AC

Klimczak, A., and Kozlowska, U. (2016). Mesenchymal stromal cells and tissuespecific progenitor cells: their role in tissue homeostasis. Stem Cells Int. 2016:4285215. doi: 10.1155/2016/4285215

Kranz, A., Wagner, D. C., Kamprad, M., Scholz, M., Schmidt, U. R., Nitzsche, F., et al. (2010). Transplantation of placenta-derived mesenchymal stromal cells upon experimental stroke in rats. Brain Res. 1315, 128-136. doi: 10.1016/j. brainres.2009.12.001

Lalu, M. M., Montroy, J., Dowlatshahi, D., Hutton, B., Juneau, P., Wesch, N., et al. (2020). From the lab to patients: a systematic review and meta-analysis of mesenchymal stem cell therapy for stroke. Transl. Stroke Res. 11, 345-364. doi: 10.1007/s12975-019-00736-5

Laskowitz, D. T., Bennett, E. R., Durham, R. J., Volpi, J. J., Wiese, J. R., Frankel, M., et al. (2018). Allogeneic umbilical cord blood infusion for adults with ischemic stroke: clinical outcomes from a phase I safety study. Stem Cells Transl. Med. 7, 521-529. doi: 10.1002/sctm.18-0008

Laso-Garcia, F., Diekhorst, L., Gomez-de Frutos, M. C., Otero-Ortega, L., Fuentes, B., Ruiz-Ares, G., et al. (2019). Cell-based therapies for stroke: promising solution or dead end? Mesenchymal stem cells and comorbidities in preclinical stroke research. Front. Neurol. 10:332. doi: 10.3389/fneur.2019. 00332

Lau, L. H., Lew, J., Borschmann, K., Thijs, V., and Ekinci, E. I. (2019). Prevalence of diabetes and its effects on stroke outcomes: a meta-analysis and literature review. J. Diabetes Investig. 10, 780-792. doi: 10.1111/jdi. 12932

Lee, J. S., Hong, J. M., Moon, G. J., Lee, P. H., Ahn, Y. H., Bang, O. Y., et al. (2010). A long-term follow-up study of intravenous autologous mesenchymal stem cell transplantation in patients with ischemic stroke. Stem Cells 28, 1099-1106. doi: $10.1002 /$ stem.430

Li, G., Yu, F., Lei, T., Gao, H., Li, P., Sun, Y., et al. (2016). Bone marrow mesenchymal stem cell therapy in ischemic stroke: mechanisms of action and treatment optimization strategies. Neural Regen Res. 11, 1015-1024. doi: 10. 4103/1673-5374.184506

Li, J., Li, D., Ju, X., Shi, Q., Wang, D., and Wei, F. (2012). Umbilical cord-derived mesenchymal stem cells retain immunomodulatory and anti-oxidative activities 
after neural induction. Neural Regen. Res. 7, 2663-2672. doi: 10.3969/j.issn. 1673-5374.2012.34.003

Li, X., Zhang, Y., Yeung, S. C., Liang, Y., Liang, X., Ding, Y., et al. (2014). Mitochondrial transfer of induced pluripotent stem cell-derived mesenchymal stem cells to airway epithelial cells attenuates cigarette smoke-induced damage. Am. J. Respir. Cell Mol. Biol. 51, 455-465. doi: 10.1165/rcmb.2013-0 $5290 \mathrm{C}$

Liang, X., Ding, Y., Zhang, Y., Tse, H. F., and Lian, Q. (2014). Paracrine mechanisms of mesenchymal stem cell-based therapy: current status and perspectives. Cell Transplant. 23, 1045-1059. doi: 10.3727/096368913X 667709

Liao, S. J., Huang, R. X., Su, Z. P., Zeng, J. S., Mo, J. W., Pei, Z., et al. (2013). Strokeprone renovascular hypertensive rat as an animal model for stroke studies: from artery to brain. J. Neurol. Sci. 334, 1-5. doi: 10.1016/j.jns.2013.07.2517

Liu, K., Guo, L., Zhou, Z., Pan, M., and Yan, C. (2019). Mesenchymal stem cells transfer mitochondria into cerebral microvasculature and promote recovery from ischemic stroke. Microvasc. Res. 123, 74-80. doi: 10.1016/j.mvr.2019.01. 001

Lyden, J., Grant, S., and Ma, T. (2019). Altered metabolism for neuroprotection provided by mesenchymal stem cells. Brain Circ. 5, 140-144. doi: 10.4103/bc. bc_36_19

Macleod, M. R., van der Worp, H. B., Sena, E. S., Howells, D. W., Dirnagl, U., and Donnan, G. A. (2008). Evidence for the efficacy of NXY-059 in experimental focal cerebral ischaemia is confounded by study quality. Stroke 39, 2824-2829. doi: 10.1161/STROKEAHA.108. 515957

Matthay, M. A., Calfee, C. S., Zhuo, H., Thompson, B. T., Wilson, J. G., Levitt, J. E., et al. (2019). Treatment with allogeneic mesenchymal stromal cells for moderate to severe acute respiratory distress syndrome (START study): a randomised phase 2a safety trial. Lancet Respir. Med. 7, 154-162. doi: 10.1016/S22132600(18)30418-1

Moisan, A., Favre, I., Rome, C., De Fraipont, F., Grillon, E., Coquery, N., et al. (2016). Intravenous injection of clinical grade human MSCs after experimental stroke: functional benefit and microvascular effect. Cell Transplant. 25, 21572171. doi: $10.3727 / 096368916$ X691132

Moniche, F., Rosado-de-Castro, P. H., Escudero, I., Zapata, E., de la Torre Laviana, F. J., Mendez-Otero, R., et al. (2016). Increasing dose of autologous bone marrow mononuclear cells transplantation is related to stroke outcome: results from a pooled analysis of two clinical trials. Stem Cells Int. 2016:8657173. doi: 10.1155/2016/8657173

Mu, J., Bakreen, A., Juntunen, M., Korhonen, P., Oinonen, E., Cui, L., et al. (2019). Combined adipose tissue-derived mesenchymal stem cell therapy and rehabilitation in experimental stroke. Front. Neurol. 10:235. doi: 10.3389/fneur. 2019.00235

Murray, L. M. A., and Krasnodembskaya, A. D. (2019). Concise review: intercellular communication via organelle transfer in the biology and therapeutic applications of stem cells. Stem Cells 37, 14-25. doi: 10.1002/stem. 2922

Napoli, E., and Borlongan, C. V. (2016). Recent advances in stem cell-based therapeutics for stroke. Transl. Stroke Res. 7, 452-457. doi: 10.1007/s12975-0160490-6

Ortega, F. J., Jolkkonen, J., Mahy, N., and Rodriguez, M. J. (2013). Glibenclamide enhances neurogenesis and improves long-term functional recovery after transient focal cerebral ischemia. J. Cereb. Blood Flow Metab. 33, 356-364. doi: $10.1038 / j \mathrm{cbfm} .2012 .166$

Perteghella, S., Martella, E., de Girolamo, L., Perucca Orfei, C., Pierini, M., Fumagalli, V., et al. (2017). Fabrication of innovative silk/alginate microcarriers for mesenchymal stem cell delivery and tissue regeneration. Int. J. Mol. Sci. 18:1829. doi: 10.3390/ijms 18091829

Pinho, A. G., Cibrao, J. R., Silva, N. A., Monteiro, S., and Salgado, A. J. (2020). Cell secretome: basic insights and therapeutic opportunities for CNS disorders. Pharmaceuticals (Basel) 13:31. doi: 10.3390/ph13020031

Powers, W. J., Derdeyn, C. P., Biller, J., Coffey, C. S., Hoh, B. L., Jauch, E. C., et al. (2015). 2015 American heart association/American stroke association focused update of the 2013 guidelines for the early management of patients with acute ischemic stroke regarding endovascular treatment: a guideline for healthcare professionals from the American heart association/American stroke association. Stroke 46, 3020-3035. doi: 10.1161/STR.0000000000 000074

Ra, J. C., Shin, I. S., Kim, S. H., Kang, S. K., Kang, B. C., Lee, H. Y., et al. (2011). Safety of intravenous infusion of human adipose tissue-derived mesenchymal stem cells in animals and humans. Stem Cells Dev. 20, 1297-1308. doi: 10.1089/ scd.2010.0466

Rastogi, L., Godbole, M. M., Ray, M., Rathore, P., Rathore, P., Pradhan, S., et al. (2006). Reduction in oxidative stress and cell death explains hypothyroidism induced neuroprotection subsequent to ischemia/reperfusion insult. Exp. Neurol. 200, 290-300. doi: 10.1016/j.expneurol.2006.02.013

Rehman, J., Traktuev, D., Li, J., Merfeld-Clauss, S., Temm-Grove, C. J., Bovenkerk, J. E., et al. (2004). Secretion of angiogenic and antiapoptotic factors by human adipose stromal cells. Circulation 109, 1292-1298. doi: 10.1161/01.CIR. 0000121425.42966.F1

Rehni, A. K., Liu, A., Perez-Pinzon, M. A., and Dave, K. R. (2017). Diabetic aggravation of stroke and animal models. Exp. Neurol. 292, 63-79. doi: 10.1016/ j.expneurol.2017.03.004

Reiner, A. T., Witwer, K. W., van Balkom, B. W. M., de Beer, J., Brodie, C., Corteling, R. L., et al. (2017). Concise review: developing best-practice models for the therapeutic use of extracellular vesicles. Stem Cells Transl. Med. 6, 1730-1739. doi: 10.1002/sctm.17-0055

Roy-O'Reilly, M., and McCullough, L. D. (2014). Sex differences in stroke: the contribution of coagulation. Exp. Neurol. 259, 16-27. doi: 10.1016/j.expneurol. 2014.02.011

Saraf, J., Sarmah, D., Vats, K., Kaur, H., Pravalika, K., Wanve, M., et al. (2019). Intra-arterial stem cell therapy modulates neuronal calcineurin and confers neuroprotection after ischemic stroke. Int. J. Neurosci. 129, 1039-1044. doi: $10.1080 / 00207454.2019 .1633315$

Saver, J. L., Goyal, M., van der Lugt, A., Menon, B. K., Majoie, C. B., Dippel, D. W., et al. (2016). Time to treatment with endovascular thrombectomy and outcomes from ischemic stroke: a meta-analysis. JAMA 316, 1279-1288. doi: 10.1001/jama.2016.13647

Savitz, S. I., Yavagal, D., Rappard, G., Likosky, W., Rutledge, N., Graffagnino, C., et al. (2019). A phase 2 randomized, sham-controlled trial of internal carotid artery infusion of autologous bone marrow-derived ALD-401 cells in patients with recent stable ischemic stroke (RECOVERstroke). Circulation 139, 192-205. doi: 10.1161/CIRCULATIONAHA.117. 030659

Shen, L. H., Li, Y., Chen, J., Cui, Y., Zhang, C., Kapke, A., et al. (2007a). One-year follow-up after bone marrow stromal cell treatment in middle-aged female rats with stroke. Stroke 38, 2150-2156. doi: 10.1161/STROKEAHA.106. 481218

Shen, L. H., Li, Y., Chen, J., Zacharek, A., Gao, Q., Kapke, A., et al. (2007b). Therapeutic benefit of bone marrow stromal cells administered 1 month after stroke. J. Cereb. Blood Flow Metab. 27, 6-13. doi: 10.1038/sj.jcbfm.96 00311

Shi, W., Huang, C. J., Xu, X. D., Jin, G. H., Huang, R. Q., Huang, J. F., et al. (2016). Transplantation of RADA16-BDNF peptide scaffold with human umbilical cord mesenchymal stem cells forced with CXCR4 and activated astrocytes for repair of traumatic brain injury. Acta Biomater. 45, 247-261. doi: 10.1016/j. actbio.2016.09.001

Shi, Y., Su, J., Roberts, A. I., Shou, P., Rabson, A. B., and Ren, G. (2012). How mesenchymal stem cells interact with tissue immune responses. Trends Immunol. 33, 136-143. doi: 10.1016/j.it.2011.11.004

Shichinohe, H., Kawabori, M., Iijima, H., Teramoto, T., Abumiya, T., Nakayama, N., et al. (2017). Research on advanced intervention using novel bone marrOW stem cell (RAINBOW): a study protocol for a phase I, open-label, uncontrolled, dose-response trial of autologous bone marrow stromal cell transplantation in patients with acute ischemic stroke. BMC Neurol. 17:179. doi: 10.1186/s12883017-0955-6

Sinden, J. D., Vishnubhatla, I., and Muir, K. W. (2012). Prospects for stem cellderived therapy in stroke. Prog. Brain Res. 201, 119-167. doi: 10.1016/B978-0444-59544-7.00007-X

Smith, W. S. (2019). Endovascular stroke therapy. Neurotherapeutics 16, 360-368. doi: 10.1007/s13311-019-00724-5

Son, J. W., Park, J., Kim, Y. E., Ha, J., Park, D. W., Chang, M. S., et al. (2019). Glia-like cells from late-passage human MSCs protect against ischemic stroke 
through IGFBP-4. Mol. Neurobiol. 56, 7617-7630. doi: 10.1007/s12035-0191629-8

Spees, J. L., Olson, S. D., Whitney, M. J., and Prockop, D. J. (2006). Mitochondrial transfer between cells can rescue aerobic respiration. Proc. Natl. Acad. Sci. U.S.A. 103, 1283-1288. doi: 10.1073/pnas.05105 11103

Squillaro, T., Peluso, G., and Galderisi, U. (2016). Clinical trials with mesenchymal stem cells: an update. Cell Transplant. 25, 829-848. doi: 10.3727/ 096368915 X689622

Steinberg, G. K., Kondziolka, D., Wechsler, L. R., Lunsford, L. D., Coburn, M. L., Billigen, J. B., et al. (2016). Clinical outcomes of transplanted modified bone marrow-derived mesenchymal stem cells in stroke: a phase $1 / 2$ a study. Stroke 47, 1817-1824. doi: 10.1161/STROKEAHA.116.012995

Steinberg, G. K., Kondziolka, D., Wechsler, L. R., Lunsford, L. D., Kim, A. S., Johnson, J. N., et al. (2018). Two-year safety and clinical outcomes in chronic ischemic stroke patients after implantation of modified bone marrow-derived mesenchymal stem cells (SB623): a phase 1/2a study. J. Neurosurg. 5, 1-11. doi: $10.3171 / 2018.5$.JNS173147

Stonesifer, C., Corey, S., Ghanekar, S., Diamandis, Z., Acosta, S. A., and Borlongan, C. V. (2017). Stem cell therapy for abrogating stroke-induced neuroinflammation and relevant secondary cell death mechanisms. Prog. Neurobiol. 158, 94-131. doi: 10.1016/j.pneurobio.2017. 07.004

Strioga, M., Viswanathan, S., Darinskas, A., Slaby, O., and Michalek, J. (2012). Same or not the same? Comparison of adipose tissue-derived versus bone marrowderived mesenchymal stem and stromal cells. Stem Cells Dev. 21, 2724-2752. doi: $10.1089 /$ scd.2011.0722

Suda, S., Nito, C., Yokobori, S., Sakamoto, Y., Nakajima, M., Sowa, K., et al. (2020). Recent advances in cell-based therapies for ischemic stroke. Int. J. Mol. Sci. 21:6718. doi: 10.3390/ijms21186718

Tobin, M. K., Bonds, J. A., Minshall, R. D., Pelligrino, D. A., Testai, F. D., and Lazarov, O. (2014). Neurogenesis and inflammation after ischemic stroke: what is known and where we go from here. J. Cereb. Blood Flow Metab. 34, 1573-1584. doi: 10.1038/jcbfm.2014.130

Toyoshima, A., Yasuhara, T., and Date, I. (2017). Mesenchymal stem cell therapy for ischemic stroke. Acta Med. Okayama 71, 263-268. doi: 10.18926/AMO/ 55302

Toyoshima, A., Yasuhara, T., Kameda, M., Morimoto, J., Takeuchi, H., Wang, F., et al. (2015). Intra-arterial transplantation of allogeneic mesenchymal stem cells mounts neuroprotective effects in a transient ischemic stroke model in rats: analyses of therapeutic time window and its mechanisms. PLoS One 10:e127302. doi: 10.1371/journal.pone.01 27302

Tseng, N., Lambie, S. C., Huynh, C. Q., Sanford, B., Patel, M., Herson, P. S., et al. (2020). Mitochondrial transfer from mesenchymal stem cells improves neuronal metabolism after oxidant injury in vitro: the role of Mirol. J. Cereb. Blood Flow Metab. 1-10. doi: 10.1177/0271678X20928147

Uccelli, A., Moretta, L., and Pistoia, V. (2006). Immunoregulatory function of mesenchymal stem cells. Eur. J. Immunol. 36, 2566-2573. doi: 10.1002/eji. 200636416

van de Vyver, M. (2017). Intrinsic mesenchymal stem cell dysfunction in diabetes mellitus: implications for autologous cell therapy. Stem Cells Dev. 26, 10421053. doi: $10.1089 / \mathrm{scd} .2017 .0025$

Venkat, P., Zacharek, A., Landschoot-Ward, J., Wang, F., Culmone, L., Chen, Z., et al. (2020). Exosomes derived from bone marrow mesenchymal stem cells harvested from type two diabetes rats promotes neurorestorative effects after stroke in type two diabetes rats. Exp. Neurol. 334:113456. doi: 10.1016/j. expneurol.2020.113456

Volarevic, V., Ljujic, B., Stojkovic, P., Lukic, A., Arsenijevic, N., and Stojkovic, M. (2011). Human stem cell research and regenerative medicine-present and future. Br. Med. Bull. 99, 155-168. doi: 10.1093/bmb/ldr027

Volarevic, V., Markovic, B. S., Gazdic, M., Volarevic, A., Jovicic, N., Arsenijevic, N., et al. (2018). Ethical and safety issues of stem cell-based therapy. Int. J. Med. Sci. 15, 36-45. doi: 10.7150/ijms. 21666

Vu, Q., Xie, K., Eckert, M., Zhao, W., and Cramer, S. C. (2014). Meta-analysis of preclinical studies of mesenchymal stromal cells for ischemic stroke. Neurology 82, 1277-1286. doi: 10.1212/WNL.0000000000000278

Wagner, W., Horn, P., Castoldi, M., Diehlmann, A., Bork, S., Saffrich, R., et al. (2008). Replicative senescence of mesenchymal stem cells: a continuous and organized process. PLoS One 3:e2213. doi: 10.1371/journal.pone.00 02213

Walczak, P., Zhang, J., Gilad, A. A., Kedziorek, D. A., Ruiz-Cabello, J., Young, R. G., et al. (2008). Dual-modality monitoring of targeted intraarterial delivery of mesenchymal stem cells after transient ischemia. Stroke 39, 1569-1574. doi: 10.1161/STROKEAHA.107.502047

Wan Safwani, W. K. Z., Choi, J. R., Yong, K. W., Ting, I., Mat Adenan, N. A., and Pingguan-Murphy, B. (2017). Hypoxia enhances the viability, growth and chondrogenic potential of cryopreserved human adiposederived stem cells. Cryobiology 75, 91-99. doi: 10.1016/j.cryobiol.2017. 01.006

Wang, C., Cheng, L., Xu, H., and Liu, Z. (2012). Towards whole-body imaging at the single cell level using ultra-sensitive stem cell labeling with oligo-arginine modified upconversion nanoparticles. Biomaterials 33, 4872-4881. doi: 10. 1016/j.biomaterials.2012.03.047

Wechsler, L. R., Bates, D., Stroemer, P., Andrews-Zwilling, Y. S., and Aizman, I. (2018). Cell therapy for chronic stroke. Stroke 49, 1066-1074. doi: 10.1161/ STROKEAHA.117.018290

Wei, L., Wei, Z. Z., Jiang, M. Q., Mohamad, O., and Yu, S. P. (2017). Stem cell transplantation therapy for multifaceted therapeutic benefits after stroke. Prog. Neurobiol. 157, 49-78. doi: 10.1016/j.pneurobio.2017.03.003

Weiss, A. R. R., and Dahlke, M. H. (2019). Immunomodulation by mesenchymal stem cells (MSCs): mechanisms of action of living, apoptotic, and dead MSCs. Front. Immunol. 10:1191. doi: 10.3389/fimmu.2019.01191

Williams, A. R., and Hare, J. M. (2011). Mesenchymal stem cells: biology, pathophysiology, translational findings, and therapeutic implications for cardiac disease. Circ. Res. 109, 923-940. doi: 10.1161/CIRCRESAHA.111. 243147

Williams, B. A., and Keating, A. (2008). Cell therapy for age-related disorders: myocardial infarction and stroke-a mini-review. Gerontology 54, 300-311. doi: $10.1159 / 000156223$

Wu, X., Jiang, J., Gu, Z., Zhang, J., Chen, Y., and Liu, X. (2020). Mesenchymal stromal cell therapies: immunomodulatory properties and clinical progress. Stem Cell Res. Ther. 11:345. doi: 10.1186/s13287-020-01855-9

Wu, Y., Hoogduijn, M. J., Baan, C. C., Korevaar, S. S., de Kuiper, R., Yan, L., et al. (2017). Adipose tissue-derived mesenchymal stem cells have a heterogenic cytokine secretion profile. Stem Cells Int. 2017:4960831. doi: 10.1155/2017/ 4960831

Xin, H., Li, Y., Cui, Y., Yang, J. J., Zhang, Z. G., and Chopp, M. (2013a). Systemic administration of exosomes released from mesenchymal stromal cells promote functional recovery and neurovascular plasticity after stroke in rats. J. Cereb. Blood Flow Metab. 33, 1711-1715. doi: 10.1038/jcbfm.20 13.152

Xin, H., Li, Y., Liu, Z., Wang, X., Shang, X., Cui, Y., et al. (2013b). MiR-133b promotes neural plasticity and functional recovery after treatment of stroke with multipotent mesenchymal stromal cells in rats via transfer of exosomeenriched extracellular particles. Stem Cells 31, 2737-2746. doi: 10.1002/stem. 1409

Yaghoubi, Y., Movassaghpour, A., Zamani, M., Talebi, M., Mehdizadeh, A., and Yousefi, M. (2019). Human umbilical cord mesenchymal stem cells derivedexosomes in diseases treatment. Life Sci. 233:116733. doi: 10.1016/j.lfs.2019. 116733

Yang, Y., Ye, G., Zhang, Y. L., He, H. W., Yu, B. Q., Hong, Y. M., et al. (2020). Transfer of mitochondria from mesenchymal stem cells derived from induced pluripotent stem cells attenuates hypoxia-ischemia-induced mitochondrial dysfunction in PC12 cells. Neural Regen. Res. 15, 464-472. doi: 10.4103/16735374.266058

Yin, F., Wang, W. Y., and Jiang, W. H. (2019). Human umbilical cord mesenchymal stem cells ameliorate liver fibrosis in vitro and in vivo: from biological characteristics to therapeutic mechanisms. World J. Stem Cells 11, 548-564. doi: 10.4252/wjsc.v11.i8.548

Yousufuddin, M., and Young, N. (2019). Aging and ischemic stroke. Aging (Albany NY) 11, 2542-2544. doi: 10.18632/aging.101931

Zhang, J., Huang, X., Wang, H., Liu, X., Zhang, T., Wang, Y., et al. (2015). The challenges and promises of allogeneic mesenchymal stem cells for use as a cell-based therapy. Stem Cell Res. Ther. 6:234. doi: 10.1186/s13287-015-0240-9

Zhang, Q., Chen, Z. W., Zhao, Y. H., Liu, B. W., Liu, N. W., Ke, C. C., et al. (2017). Bone marrow stromal cells combined with Sodium Ferulate and n-Butylidenephthalide promote the effect of therapeutic angiogenesis 
via advancing astrocyte-derived trophic factors after ischemic stroke. Cell Transplant. 26, 229-242. doi: 10.3727/096368916X693536

Zhang, Y., Chopp, M., Meng, Y., Katakowski, M., Xin, H., Mahmood, A., et al. (2015). Effect of exosomes derived from multipluripotent mesenchymal stromal cells on functional recovery and neurovascular plasticity in rats after traumatic brain injury. J. Neurosurg. 122, 856-867. doi: 10.3171/2014.11.JNS 14770

Zhang, Z. G., Buller, B., and Chopp, M. (2019). Exosomes - beyond stem cells for restorative therapy in stroke and neurological injury. Nat. Rev. Neurol. 15, 193-203. doi: 10.1038/s41582-018-0126-4
Conflict of Interest: The authors declare that the research was conducted in the absence of any commercial or financial relationships that could be construed as a potential conflict of interest.

Copyright $\odot 2021 \mathrm{Li}$, Shi, Hu, Hong, Zhang, Li and Zhang. This is an open-access article distributed under the terms of the Creative Commons Attribution License (CC BY). The use, distribution or reproduction in other forums is permitted, provided the original author(s) and the copyright owner(s) are credited and that the original publication in this journal is cited, in accordance with accepted academic practice. No use, distribution or reproduction is permitted which does not comply with these terms. 